\title{
Pertumbuhan Tithonia diversifolia dengan Dosis Pupuk Kandang dan Jarak Tanam yang Berbeda
}

\section{Growth of Tithonia diversifolia on Different Chicken Manure Rates and Planting Distances}

\author{
Lia Desyrakhmawati ${ }^{1,2}$, Maya Melati ${ }^{3 *}$, Suwarto $^{3}$, dan Wiwik Hartatik ${ }^{4}$ \\ ${ }^{1}$ Progam Studi Agronomi dan Hortikultura, Sekolah Pascasarjana, Institut Pertanian Bogor \\ ${ }^{2}$ Dinas Pertanian, Perkebunan dan Kehutanan Kota Samarinda, Jl. Biola No.1, Samarinda 75123, Indonesia \\ ${ }^{3}$ Departemen Agronomi dan Hortikultura, Fakultas Pertanian, Institut Pertanian Bogor \\ (Bogor Agricultural University), Jl. Meranti, Kampus IPB, Darmaga, Bogor 16680, Indonesia \\ ${ }^{4}$ Balai Penelitian Tanah Bogor, Jl. Tentara Pelajar No.12 Bogor 16114, Indonesia
}

Diterima 8 Januari 2014/Disetujui 3 Juni 2014

\begin{abstract}
Mexican sunflower (Tithonia diversifolia) is a invansive weed but it can be used as continuous and on-farm source of nutrient for organic farming system. The objective of this study was to investigate growth and biomass production of $\underline{T}$. diversifolia with different rates of chicken manure and plant spacings. The experiment was conducted at Cikarawang, Bogor, on Inceptisol soil type, from October 2011 until January 2012. The experiment was arranged in a randomized block design with 2 factors and 3 replications. The rates of chicken manure were 0, 2.5, 5 and 10 ton ha ${ }^{-1}$, while the plant spacings were $50 \mathrm{~cm} \times 50 \mathrm{~cm}$ and $75 \mathrm{~cm} \times 75 \mathrm{~cm}$. The interaction effect between manure rates and plant spacing was significant on nett assimilation rate at 4-8 weeks after planting, but it was not significant on biomass production. The highest dry weight of biomass $\left(1,129.1 \mathrm{~kg} \mathrm{ha}^{-1}\right)$ was obtained from the addition of 10 ton chicken manure hal with the potential contribution as much as $55.47 \mathrm{~kg} \mathrm{~N}, 4.54 \mathrm{~kg} P, 88.54 \mathrm{~kg} \mathrm{~K}$ per hectare. The highest dry weight of biomass produced with planting distance $50 \mathrm{~cm} \times 50 \mathrm{~cm}\left(897 \mathrm{~kg} \mathrm{ha^{-1 }}\right)$. Referring to the results, it can be recommended that the cultivation of $\underline{T}$. diversifolia at the first planting needs 10 ton chicken manure ha $\mathrm{a}^{-1}$ and the planting distance of $50 \mathrm{~cm} \times 50 \mathrm{~cm}$.
\end{abstract}

Keywords: biomass production, Mexican sun flower, nett assimilation ratio, nutrient contributio, weed

\section{ABSTRAK}

Bunga matahari Mexico (Tithonia diversifolia) adalah gulma yang invasif tetapi memiliki potensi sebagai sumber hara yang berkelanjutan pada sistem pertanian organik. Tujuan penelitian ini adalah mempelajari pengaruh pupuk kandang ayam dan jarak tanam terhadap pertumbuhan dan produksi biomassa $\underline{T}$. diversifolia. Percobaan dilaksanakan pada bulan Oktober 2011 hingga Januari 2012 di Kebun Percobaan IPB Desa Cikarawang, Bogor, jenis tanah Inceptisol. Percobaan ini menggunakan kelompok lengkap teracak dengan 2 faktor terdiri atas dosis pupuk kandang (0, 2.5, 5 dan 10 ton ha $\left.{ }^{-1}\right)$ dan jarak tanam $(50 \mathrm{~cm} \times 50 \mathrm{~cm}$ dan $75 \mathrm{~cm} \times 75 \mathrm{~cm})$ dengan 3 ulangan. Hasil penelitian menunjukkan bahwa pengaruh interaksi antara dosis pupuk kandang dan jarak tanam nyata pada laju asimilasi bersih umur 4-8 minggu setelah tanam namun tidak nyata pada produksi biomassa pucuk. Bobot kering biomassa tertinggi $\left(1,129.1 \mathrm{~kg} \mathrm{ha}^{-1}\right)$ dihasilkan dari pemberian 10 ton pupuk kandang ha-1 dengan potensi sumbangan haranya $55.47 \mathrm{~kg} \mathrm{~N}, 4.54 \mathrm{~kg} P$ dan $88.54 \mathrm{~kg} \mathrm{~K} \mathrm{per} \mathrm{hektar.} \mathrm{Bobot} \mathrm{kering}$

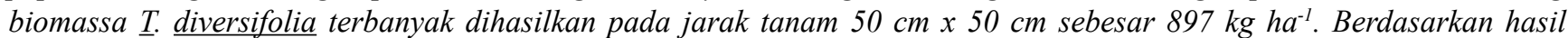

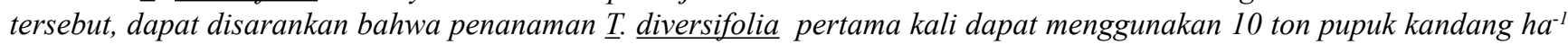
dengan jarak tanam $50 \mathrm{~cm} \times 50 \mathrm{~cm}$.

Kata kunci: Bunga matahari Mexico, gulma, laju asimilasi bersih, produksi biomassa, sumbangan hara

\section{PENDAHULUAN}

Tithonia diversifolia disebut juga sebagai tree marigold, bunga matahari Mexico atau kembang bulan. Awalnya $T$. diversifolia dikenal sebagai tumbuhan liar yang

\footnotetext{
* Penulis untuk korespondensi. e-mail: maya_melati05@yahoo. com
}

sangat agresif membentuk koloni sehingga menjadi gulma bagi tanaman budidaya (Chukwuka et al., 2007a) tetapi kemudian diketahui bahwa T. diversifolia dapat dimanfaatkan sebagai pupuk hijau (Opala et al., 2009; Crespo et al., 2011). Daun T. diversifolia kering mengandung 3.5-4.0\% $\mathrm{N}, \quad 0.35-0.38 \% \mathrm{P}, 3.5-4.1 \% \mathrm{~K}, 0.59 \% \mathrm{Ca}$, dan $0.27 \% \mathrm{Mg}$ sehingga hijauan $T$. diversifolia berpotensi sebagai sumber hara N, P, K bagi tanaman (Hartatik, 2007). Pemanfaatan T. diversifolia sebagai sumber hara selain berupa pupuk 
hijau segar atau pupuk hijau cair dapat pula berupa kompos (Muhsanati et al., 2008; Hakim et al., 2012) dan mulsa (Liasu dan Achakzai, 2007; Adeniyan et al., 2008). T. diversifolia juga bermanfaat untuk meningkatkan kesuburan tanah (Oelbermann et al., 2012; Ojeniyi et al., 2012), sebagai pestisida nabati (Oyedokun et al., 2011; Akpheokhai et al., 2012) dan farmasi (Chagas-Paula et al., 2012). Hasil analisis fitokimia biomassa $T$. diversifolia menunjukkan bahwa tanaman ini dapat dimanfaatkan sebagai tanaman obat, karena mengandung senyawa kimia saponin, alkaloid, tanin, flavonoid, steroid dan glikosida yang berperan penting dalam pengobatan. Hal ini juga membuktikan pemanfaatan daun $T$. diversifolia dalam pengobatan tradisional untuk berbagai macam penyakit (Essiett dan Uriah, 2013) dan dalam pengobatan herbal (Essiett dan Akpan, 2013).

Potensi $T$. diversifolia sebagai pupuk hijau dan sebagai pestisida nabati menjadi pertimbangan untuk membudidayakannya. Selama ini biomassa $T$. diversifolia diperoleh dari tanaman yang tumbuh secara liar di tepi lahan pertanian, di lereng-lereng tebing dan di tepi-tepi jalan raya. Jika $T$. diversifolia dibudidayakan pada lokasi yang berdekatan dengan tempat budidaya tanaman lain, diharapkan bahwa tajuknya dapat dipanen secara berkala sehingga dapat digunakan sebagai sumber hara jangka panjang terutama dalam sistem pertanian organik.

Kelebihan lain dari biomassa $T$. diversifolia adalah mempunyai kadar unsur K lebih tinggi daripada Centrosema pubescens dan Calopogonium mucunoides. Percobaan yang dilakukan oleh Barus (2005) menunjukkan bahwa daun C. mucunoides mengandung $2.47 \% \mathrm{~N}, 0.23 \% \mathrm{P}, 0.75 \%$ $\mathrm{K}$ sedangkan daun $C$. pubescens mengandung $3.49 \%$, $0.36 \%$ P, $1.05 \%$ K. Hasil percobaan Kurniansyah (2010) menunjukkan bahwa kandungan daun $T$. diversifolia adalah $3.06 \% \mathrm{~N}, 0.25 \% \mathrm{P}$, dan $5.75 \% \mathrm{~K}$ dan menyebabkan intensitas serangan hama dan pathogen yang lebih rendah serta produksi kedelai yang lebih tinggi pada tanaman yang mendapat $T$. diversifolia dibandingkan yang mendapat $C$. pubescens. Percobaan ini juga memperlihatkan bahwa, dengan jumlah yang sama, waktu yang dibutuhkan untuk dekomposisi tajuk $T$. diversifolia lebih singkat daripada untuk C. pubescens.

Berdasarkan manfaat $T$. diversifolia sebagai sumber hara, maka perlu dilakukan kajian untuk budidaya tanaman ini. Penanaman T. diversifolia pertama kali memerlukan input berupa pupuk organik jika biomassa tanaman ini akan digunakan dalam sistem pertanian organik. Oleh karena itu perlu dilakukan pemberian bahan organik pada awal budidayanya karena transfer unsur hara berkelanjutan dalam periode yang panjang tidak akan tercukupi dari produksi biomassa $T$. diversifolia yang rendah (Jama et al., 2000).

Pupuk kandang merupakan satu jenis bahan organik yang umumnya digunakan dalam budidaya pertanian dengan tujuan untuk memperbaiki sifat fisik, kimia dan biologi tanah. Pupuk kandang ayam memiliki keunggulan dibandingkan dengan pupuk kandang sapi dan pupuk kandang kambing karena kandungan unsur haranya relatif lebih tinggi dan kadar air lebih rendah sehingga aplikasi pupuk kandang ayam dalam unit yang sama dengan pupuk kandang sapi atau pupuk kandang kambing akan menyumbangkan unsur hara yang lebih tinggi (Hayati, 2013). Oleh karena itu penggunaan pupuk kandang ayam dalam budidaya pertanian dapat meningkatkan hasil pertanian (Melati dan Andriyani, 2005; Sistani et al., 2007; Melati et al., 2008; Laude dan Tambing, 2010).

Pengaturan jarak tanam dimaksudkan untuk memberi ruang tumbuh yang cukup bagi tanaman yang dibudidayakan sehingga mengurangi persaingan antar tanaman. Perbedaan jarak tanam mampu meningkatkan indeks pertumbuhan fisiologis tanaman (Farahani dan Valadabadi, 2009), mempengaruhi pertumbuhan diameter batang dan tinggi tanaman (Badi et al., 2004), meningkatkan evaporasi tanah dan transpirasi tanaman (Chen et al., 2010).

Penggunaan pupuk kandang ayam dan pengaturan jarak tanam merupakan unsur budidaya yang dapat meningkatkan produksi tanaman kentang (Fatkur et al., 2010) dan menekan pertumbuhan gulma (Mayadewi, 2007). $T$. diversifolia memiliki pertumbuhan yang cepat dengan cabang yang banyak sehingga membutuhkan ruang tumbuh yang cukup lebar, tetapi belum ditemukan jarak tanam optimum bagi budidaya $T$. diversifolia selain dalam bentuk teknik budidaya lorong. Kombinasi perlakuan pemberian pupuk kandang dan pengaturan jarak tanam diharapkan mampu meningkatkan pertumbuhan $T$. diversifolia sehingga dapat dicapai produksi optimum hijauannya.

Tithonia diversifolia belum pernah dibudidayakan. Tujuan dari penelitian ini adalah untuk mengetahui pengaruh pupuk kandang ayam dan jarak tanam terhadap pertumbuhan dan produksi biomassa Tithonia diversifolia.

\section{BAHAN DAN METODE}

Percobaan dilaksanakan di Kebun Percobaan IPB Desa Cikarawang, Darmaga, Bogor, terletak pada ketinggian 224 $\mathrm{m}$ dpl dengan jenis tanah Inceptisol. Percobaan berlangsung dari bulan Oktober 2011 sampai dengan Januari 2012.

Penelitian ini disusun dalam rancangan kelompok lengkap teracak dengan 2 faktor dan 3 ulangan. Faktor pertama adalah dosis pupuk kandang ayam petelur yaitu 0 , 2.5, 5 dan 10 ton ha $^{-1}$. Faktor ke-2 adalah jarak tanam yaitu $50 \mathrm{~cm} \times 50 \mathrm{~cm}$ dan $75 \mathrm{~cm} \times 75 \mathrm{~cm}$. Tanaman contoh terdiri atas 6 tanaman per petak.

Petak percobaan berukuran $4.5 \mathrm{~m}$ x $4.5 \mathrm{~m}$ dan jarak antar petak $30 \mathrm{~cm}$. Bahan tanam $T$. diversifolia berasal dari bibit stek batang sepanjang $\pm 20 \mathrm{~cm}$ yang telah ditanam terlebih dahulu dalam polibag selama 4 minggu. Populasi tanaman per petak untuk jarak tanam $50 \mathrm{~cm}$ x $50 \mathrm{~cm}$ dan $75 \mathrm{~cm}$ x $75 \mathrm{~cm}$ masing-masing adalah 81 dan 36 tanaman. Pupuk kandang diberikan dua minggu sebelum waktu tanam pada lubang tanam, dosis pupuk 2.5, 5 dan 10 ton ha ${ }^{-1}$ dengan jarak tanam $50 \mathrm{~cm}$ x $50 \mathrm{~cm}$ menjadi 62, 125 dan 250 g per lubang tanam, sedangkan untuk jarak tanam $75 \mathrm{~cm} \mathrm{x}$ $75 \mathrm{~cm}$ menjadi 138, 300 dan $600 \mathrm{~g}$ per lubang tanam.

Terhadap 6 tanaman sampel dilakukan pengamatan tinggi tanaman, jumlah cabang utama, jumlah cabang 
sekunder, jumlah daun, lebar tajuk, diameter batang pada umur 4 dan 8 MST dan panen biomassa pada umur 8 MST. Panen dilakukan dengan memotong $30 \mathrm{~cm}$ daun dan batang lunak bagian pucuk. Pengambilan sampel destruktif dilakukan dengan mencabut 1 tanaman dari setiap petak percobaan untuk mengukur luas daun, indeks luas daun (ILD), bobot basah dan bobot kering biomassa (daun, tangkai daun, batang dan akar), laju tumbuh relatif (LTR), laju asimilasi bersih (LAB) pada umur 4 dan 8 MST. Parameter ini berguna untuk menganalisis pertumbuhan tanaman pada interval waktu tertentu $(\mathrm{t})$, dengan mengetahui bobot kering tanaman (W) dapat diukur laju pertumbuhan relatif

$\left(L T R=\frac{\ln W 2-\ln W 1}{t 2-t 1}\right)$

dan dengan mengetahui luas daun (A) serta bobot kering dapat diukur laju asimilasi bersih

$\left(L A B=\frac{(W 2-W 1)(\ln A 2-\ln A 1)}{(t 2-t 1)(A 2-A 1)}\right)$

(Leopold dan Kriedemann, 1975). Analisis hara biomassa dan analisis fitokimia biomassa dilakukan pada 8 MST. Analisis data dilakukan dengan sidik ragam. Kurva respon ditentukan dengan persamaan regresi.

\section{HASIL DAN PEMBAHASAN}

Hasil analisis ragam menunjukkan bahwa pengaruh interaksi antara dosis pupuk kandang dan jarak tanam terjadi pada peubah laju asimilasi bersih (LAB) umur 4-8 MST. Dosis pupuk kandang dan jarak tanam secara tunggal berpengaruh terhadap beberapa peubah pertumbuhan dan produksi biomassa.

Pupuk kandang nyata mempengaruhi tinggi tanaman, lebar tajuk tanaman, diameter batang pada umur 4 MST (Gambar 1) dengan pola kuadratik. Berdasarkan persamaan regresi, dosis pupuk kandang optimum untuk peubah tinggi tanaman, lebar tajuk dan diameter batang berturut-turut adalah 5.96, 6.80 dan 8.20 ton $\mathrm{ha}^{-1}$ pada umur 4 MST. Dosis pupuk kandang tidak lagi mempengaruhi pertumbuhan saat tanaman umur 8 MST.

Pemberian pupuk kandang meningkatkan LAB tanaman umur 4-8 MST dibandingkan tanpa pemberian pupuk kandang. Hanya dosis pupuk kandang 10 ton ha ${ }^{-1}$ yang nyata meningkatkan LAB tanaman bila dibandingkan dengan tanpa pemberian pupuk kandang. Dosis pupuk kandang 2.5 ton ha $^{-1}$ menyebabkan peningkatan LAB yang tidak berbeda nyata dengan perlakuan dosis pupuk kandang 5 dan 10 ton ha $^{-1}$.

Dosis pupuk kandang berpengaruh terhadap bobot basah dan bobot kering biomassa panen per tanaman, sehingga berpengaruh pula terhadap potensi produksi biomassa per hektar. Potensi bobot basah dan bobot kering biomassa panen menunjukkan kecenderungan yang masih meningkat hingga dosis pupuk kandang 10 ton ha ${ }^{1}$, (Gambar 2). Hal ini dapat diartikan bahwa dosis pupuk kandang 10
A

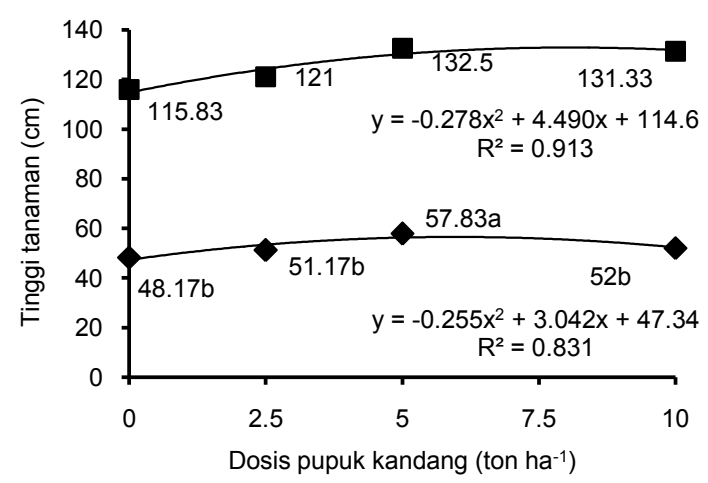

C

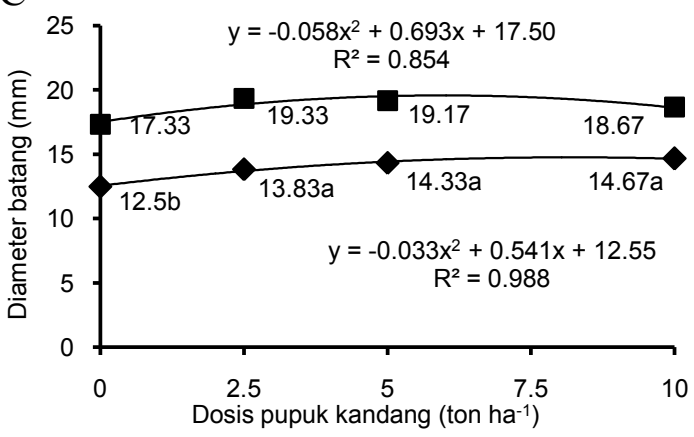

B

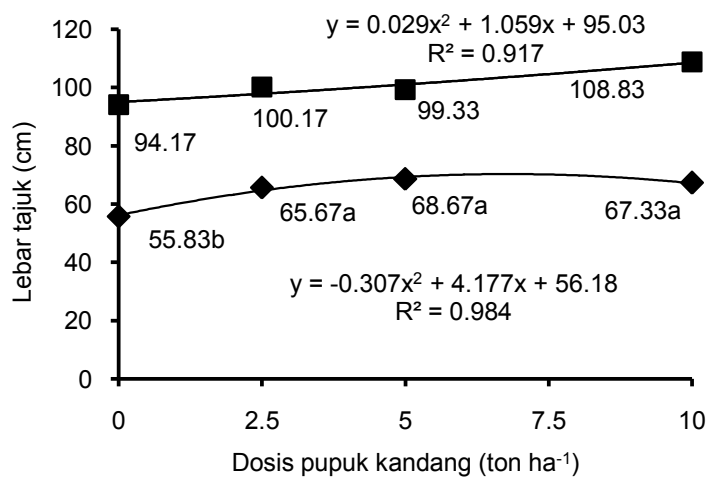

D

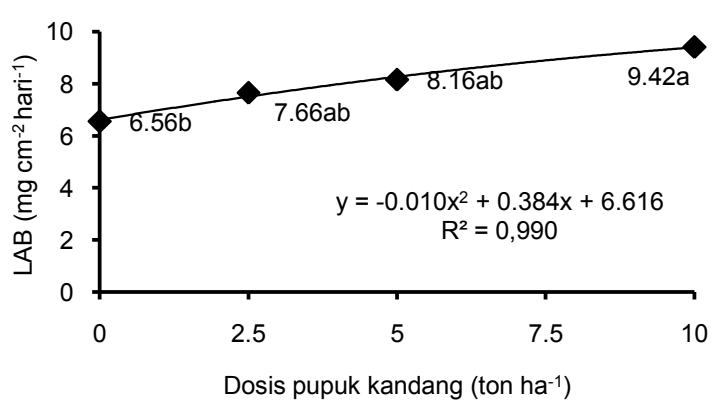

Gambar 1. Pengaruh pupuk kandang terhadap (A) tinggi tanaman; (B) lebar tajuk; (C) diameter batang; (D) Laju asimilasi bersih tanaman 4-8 MST. Angka yang diikuti huruf yang sama pada variabel dan umur tanaman yang sama menunjukkan tidak berbeda nyata berdasarkan DMRT $\alpha=5 \%$ 
ton $\mathrm{ha}^{-1}$ yang merupakan dosis pupuk kandang tertinggi, adalah dosis pupuk terbaik untuk menghasilkan biomassa tertinggi pada kedua jarak tanam.
Kadar hara dalam pucuk saat panen umur 8 MST dapat dilihat pada Tabel 1, sedangkan perkiraan sumbangan hara dari pucuk tanaman dapat dilihat pada Gambar 2. Kadar
A

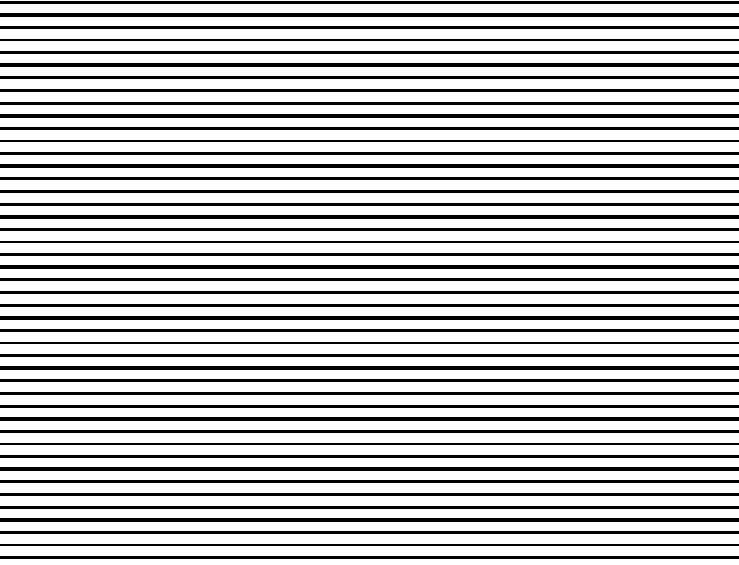

C

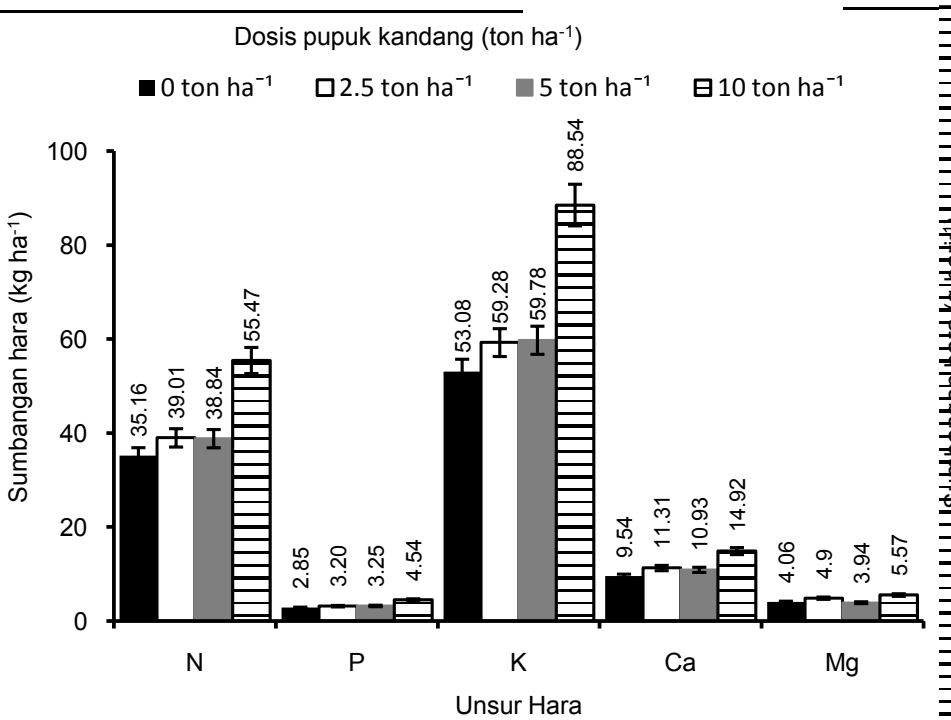

$\mathrm{B}$

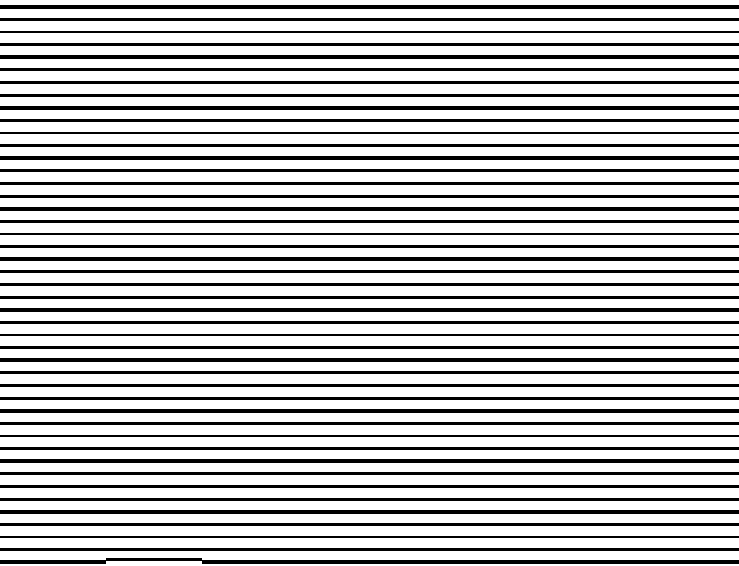

$\mathrm{D}$

Dosis pupuk kandang (ton ha-1)

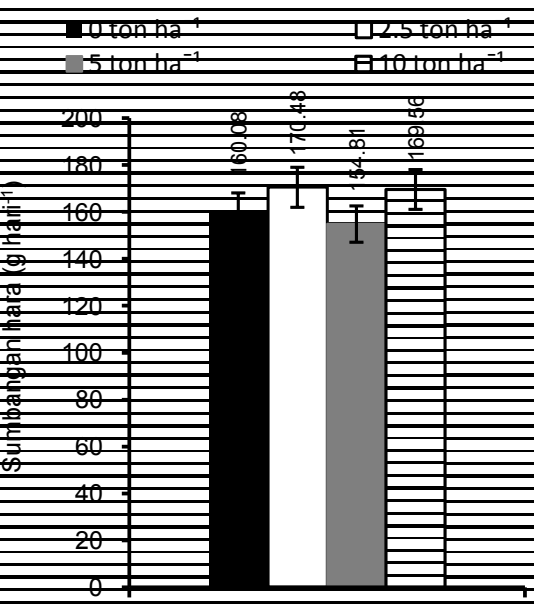

$\mathrm{Fe}$

Unsur hara

Gambar 2. Pengaruh pupuk kandang terhadap (A) bobot basah biomassa per hektar; (B) bobot kering biomassa per hektar; (C) potensi sumbangan unsur hara makro dan makro sekunder dari biomassa per hektar; (D) perkiraan sumbangan unsur hara Fe dari biomassa Tithonia diversifolia per hektar. Error bar $\pm \mathrm{SE}$

Tabel 1. Kadar hara dalam pucuk tanaman Tithonia diversifolia umur 8 MST dengan perlakuan dosis pupuk

\begin{tabular}{|c|c|c|c|c|c|}
\hline \multirow{2}{*}{$\begin{array}{l}\text { Kadar hara dalam } \\
\text { pucuk }\end{array}$} & \multicolumn{4}{|c|}{ Dosis pupuk kandang (ton $\mathrm{ha}^{-1}$ ) } & \multirow{2}{*}{ Rataan } \\
\hline & 0 & 2.5 & 5 & 10 & \\
\hline Hara makro & \multicolumn{5}{|c|}{..$\%$ bobot kering... } \\
\hline $\mathrm{N}$ & 4.95 & 4.91 & 5.11 & 4.84 & 4.95 \\
\hline $\mathrm{P}$ & 0.40 & 0.40 & 0.44 & 0.41 & 0.41 \\
\hline $\mathrm{K}$ & 7.52 & 7.42 & 8.08 & 7.86 & 7.72 \\
\hline $\mathrm{Ca}$ & 1.35 & 1.41 & 1.51 & 1.32 & 1.40 \\
\hline $\mathrm{Mg}$ & 0.57 & 0.62 & 0.53 & 0.49 & 0.55 \\
\hline \multicolumn{6}{|l|}{ Hara mikro } \\
\hline $\mathrm{Fe}$ & 223.83 & 219.67 & 220.17 & 148.67 & 203.09 \\
\hline
\end{tabular}


hara dalam pucuk dan sumbangan hara dari pucuk yang tertinggi adalah unsur hara $\mathrm{K}$. Rata-rata kadar air dari pucuk T. diversifolia adalah $89.4 \%$, dengan kadar air tersebut dapat diketahui perkiraan sumbangan hara potensial yang dapat diperoleh dari pucuk panen $T$. diversifolia yaitu dari perkalian antara bobot kering pucuk $(\mathrm{kg})$ dengan kadar unsur dalam pupuk (\%). Nilai tersebut berupa dugaan karena tidak mempertimbangkan kemungkinan kehilangan hara, kecepatan dekomposisi, dan perbedaan waktu ketersediaan hara dalam tanah (Kurniansyah, 2010). Potensi sumbangan hara $\mathrm{N}$, $\mathrm{P}$, dan $\mathrm{K}$ tertinggi dari produksi biomassa $T$. diversifolia berdasarkan perlakuan dosis pupuk kandang ditunjukkan pada perlakuan dosis pupuk kandang 10 ton ha $^{-1}$ sedangkan sumbangan unsur hara $\mathrm{Ca}, \mathrm{Mg}$ dan Fe tidak dipengaruhi oleh perlakuan dosis pupuk kandang. Perkiraan sumbangan hara jika diambil dari pucuk $T$. diversifolia sepanjang $30 \mathrm{~cm}$ setara dengan $123.27 \mathrm{~kg}$ urea, $15.36 \mathrm{~kg}$ SP-36 dan $106.93 \mathrm{~kg} \mathrm{KCl}$. Potensi sumbangan hara ini mengindikasikan peluang $T$. diversifolia untuk mengurangi penggunaan pupuk kimia sintetis terutama urea dan $\mathrm{KCl}$. Berdasarkan keragaan tanaman, pucuk dapat dipanen sampai $50 \mathrm{~cm}$ sehingga sumbangan hara juga bisa lebih tinggi.

Jarak tanam mempengaruhi tinggi tanaman, jumlah cabang sekunder, jumlah daun per tanaman umur 8 MST, lebar tajuk umur 4 dan 8 MST dan indeks luas daun (ILD) umur 4 MST. Jarak tanam lebar $(75 \mathrm{~cm}$ x $75 \mathrm{~cm})$ umumnya menyebabkan nilai peubah lebih tinggi daripada nilai peubah dengan jarak tanam rapat $(50 \mathrm{~cm}$ x $50 \mathrm{~cm})$, kecuali pada peubah tinggi tanaman umur 8 MST dan ILD umur 4 MST (Tabel 2).

Nilai komponen pertumbuhan yang lebih tinggi pada jarak tanam lebar diduga karena adanya ketersediaan ruang tumbuh yang cukup bagi pertumbuhan dan perkembangan tanaman sehingga cahaya matahari lebih mudah mencapai bagian tanaman. Cahaya merupakan faktor terpenting bagi pertumbuhan $T$. diversifolia selain air. Chukwuka et al. (2007b) melaporkan bahwa $T$. diversifolia yang tumbuh di bawah intensitas cahaya yang rendah (500 lux) mengakumulasi biomassa yang lebih rendah dibandingkan dengan akumulasi biomassa $T$. diversifolia yang tumbuh di bawah intensitas cahaya penuh.

Tanaman umur 8 MST pada jarak tanam rapat lebih tinggi dibandingkan jarak tanam lebar (Tabel 2). Diduga bahwa tanaman pada jarak tanam rapat mengalami etiolasi yaitu penambahan tinggi tanaman tanpa diikuti oleh bobot kering tanaman karena pada proses ini yang berperan adalah hormon pertumbuhan yaitu auksin. Respon ini merupakan respon fototropik tanaman terhadap keterbatasan cahaya, dimana pada jarak tanam rapat jumlah cahaya yang dapat mencapai bagian bawah tanaman semakin sedikit. Bagian batang yang ternaungi memiliki konsentrasi hormon auksin yang lebih tinggi dibandingkan bagian batang yang tidak ternaungi, sehingga mendorong pertumbuhan batang ke arah cahaya (Salisbury dan Ross, 1995).

ILD yang besar pada jarak tanam rapat saat tanaman umur 4 MST diduga karena adanya pengaruh lingkungan

Tabel 2. Komponen pertumbuhan Tithonia diversifolia dengan perlakuan jarak tanam

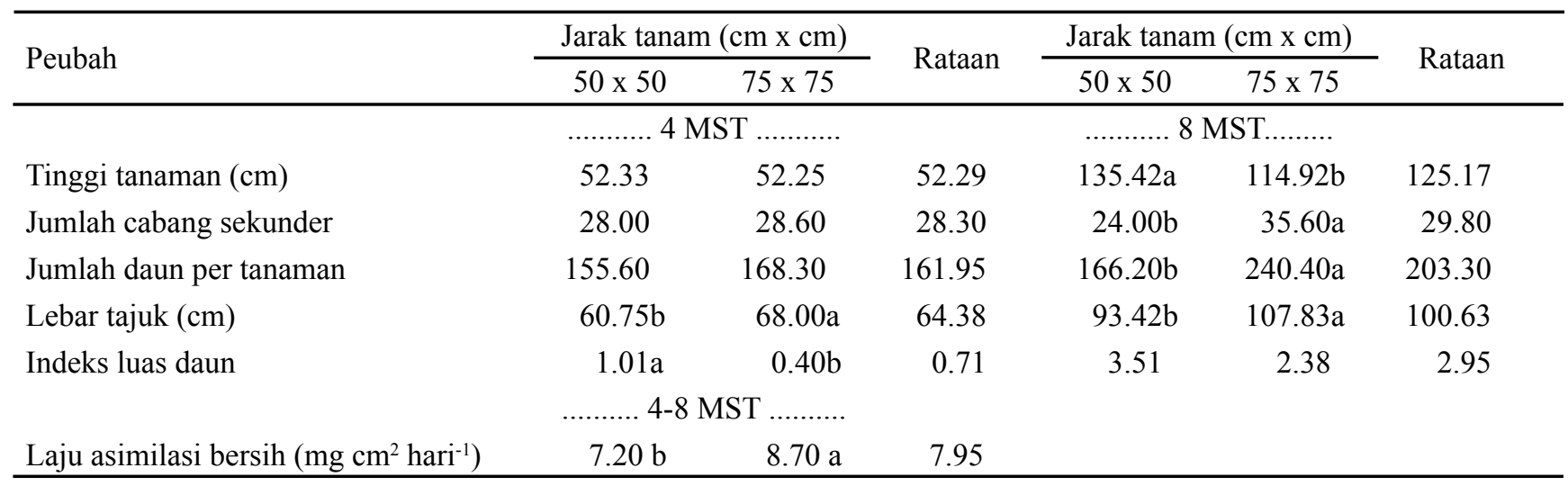

Keterangan: Angka yang diikuti oleh huruf yang sama pada baris yang sama pada tiap kelompok umur (4 MST dan 8 MST) tidak berbeda nyata berdasarkan uji DMRT pada taraf $5 \%$

Tabel 3. Komponen produksi biomassa Tithonia diversifolia pada 8 MST pada 2 jarak tanam

\begin{tabular}{|c|c|c|c|}
\hline \multirow{2}{*}{ Bobot biomassa } & \multicolumn{2}{|c|}{ Jarak tanam $(\mathrm{cm} \times \mathrm{cm})$} & \multirow{2}{*}{ Rataan } \\
\hline & $50 \times 50$ & $75 \times 75$ & \\
\hline \multicolumn{4}{|c|}{ 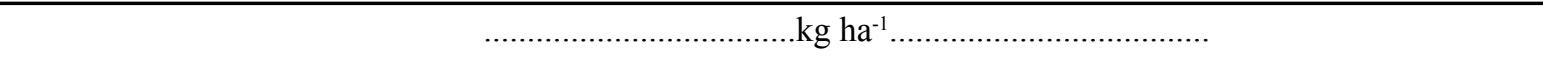 } \\
\hline Bobot basah & $8,290.0$ & $7,554.2$ & $7,922.1$ \\
\hline Bobot kering & 897.0 & 799.6 & 848.3 \\
\hline
\end{tabular}


Tabel 4. Sumbangan hara Tithonia diversifolia pada 2 jarak tanam pada 8 MST

\begin{tabular}{|c|c|c|c|}
\hline \multirow{2}{*}{ Potensi sumbangan hara } & \multicolumn{2}{|c|}{ Jarak tanam $(\mathrm{cm} \times \mathrm{cm})$} & \multirow{2}{*}{ Rataan } \\
\hline & $50 \times 50$ & $75 \times 75$ & \\
\hline \multicolumn{4}{|c|}{ 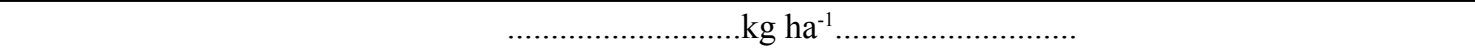 } \\
\hline $\mathrm{N}$ & 44.39 & 39.85 & 42.12 \\
\hline $\mathrm{P}$ & 3.74 & 3.19 & 3.47 \\
\hline $\mathrm{K}$ & 70.64 & 59.70 & 65.17 \\
\hline $\mathrm{Ca}$ & 12.53 & 10.83 & 11.68 \\
\hline $\mathrm{Mg}$ & 4.77 & 4.47 & 4.62 \\
\hline \multicolumn{4}{|c|}{ 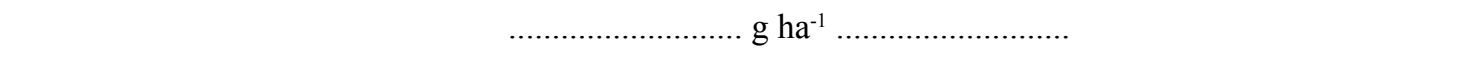 } \\
\hline $\mathrm{Fe}$ & 170.58 & 156.88 & 163.73 \\
\hline
\end{tabular}

berupa ketersediaan cahaya matahari yang terbatas bagi pertumbuhan daun. Daun tanaman dalam kondisi ternaungi memiliki permukaan lebih lebar (Repkova et al., 2009) agar daun dapat menangkap cahaya matahari lebih banyak untuk proses fotosintesis. Perluasan daun sebagai respon terhadap kurangnya cahaya juga dipengaruhi oleh faktor genetik (Volkenburgh, 1999).

Bobot basah dan bobot kering biomassa panen per tanaman serta sumbangan hara biomassa pucuk umur 8 MST lebih tinggi pada perlakuan jarak tanam lebar $(75 \mathrm{~cm}$ $\mathrm{x} 75 \mathrm{~cm})$, tetapi persatuan luas dari jarak tanam rapat (50 $\mathrm{cm} \times 50 \mathrm{~cm}$ ) menyumbang biomassa lebih tinggi (Tabel 3 dan 4). Rata-rata kadar air biomassa panen $T$. diversifolia dengan perlakuan jarak tanam adalah 89.3\%. Perkiraan sumbangan hara yang dapat diperoleh dari pucuk $T$. diversifolia sepanjang $30 \mathrm{~cm}$ setara dengan $98.64 \mathrm{~kg}$ urea, $23.97 \mathrm{~kg}$ SP-36 dan $142.32 \mathrm{~kg} \mathrm{KCl}$. Perlakuan jarak tanam tidak berpengaruh terhadap kadar hara dalam pucuk saat panen umur 8 MST (Tabel 5).

Terdapat interaksi perlakuan dosis pupuk kandang dan jarak tanam pada peubah LAB umur 4-8 MST (Gambar 3). Peningkatan dosis pupuk kandang masih meningkatkan LAB tanaman pada jarak tanam lebar, namun telah tercapai

Tabel 5. Kadar hara dalam pucuk tanaman Tithonia diversifolia umur 8 minggu setelah tanam dengan perlakuan jarak tanam

\begin{tabular}{|c|c|c|c|}
\hline \multirow{2}{*}{$\begin{array}{l}\text { Kadar hara } \\
\text { dalam pucuk }\end{array}$} & \multicolumn{2}{|c|}{ Jarak tanam $(\mathrm{cm} \mathrm{x} \mathrm{cm})$} & \multirow{2}{*}{ Rataan } \\
\hline & $50 \times 50$ & $75 \times 75$ & \\
\hline Hara makro & \multicolumn{2}{|c|}{$\ldots . . \%$ (bobot kering) $^{-1} \ldots$} & \\
\hline $\mathrm{N}$ & 5.00 & 4.90 & 4.95 \\
\hline $\mathrm{P}$ & 0.42 & 0.41 & 0.42 \\
\hline $\mathrm{K}$ & 7.90 & 7.50 & 7.70 \\
\hline $\mathrm{Ca}$ & 1.40 & 1.40 & 1.40 \\
\hline $\mathrm{Mg}$ & 0.53 & 0.58 & 0.56 \\
\hline \multicolumn{3}{|l|}{ Hara mikro } & \multirow[b]{2}{*}{203.09} \\
\hline $\mathrm{Fe}$ & 178.67 & 227.5 & \\
\hline
\end{tabular}

titik maksimum pada 5.82 ton $\mathrm{ha}^{-1}$ pada jarak tanam rapat dengan persamaan $\mathrm{y}=-0.090 \mathrm{x}^{2}+1.047 \mathrm{x}+5.578$.

Pengaruh perlakuan terhadap biomassa tanaman secara keseluruhan menunjukkan bahwa bobot basah dan bobot kering tajuk dan akar tidak berbeda antar dosis pupuk kandang maupun antar jarak tanam (Tabel 6). Meskipun tidak nyata, ada kecenderungan penambahan dosis pupuk kandang meningkatkan bobot tajuk dan akar karena adanya peningkatan LTR umur 4-8 MST dan secara nyata menurunkan rasio tajuk/akar pada $8 \mathrm{MST}$. Hasil ini menunjukkan bahwa penambahan pupuk kandang masih mendorong pertumbuhan akar sehingga diduga akar mampu mendukung pertumbuhan tajuk. Sistem perakaran pada T. diversifolia diduga mempunyai toleransi yang tinggi terhadap kondisi lingkungan yang kurang menguntungkan.

Terjadi peningkatan biomassa tajuk yang cukup tinggi saat tanaman umur 8 MST yaitu menjadi 4.3 sampai 7.4 kali biomassa tajuk pada $4 \mathrm{MST}$. Produksi biomassa $T$. diversifolia yang tinggi saat 8 MST juga dikemukan Partey (2011). Besarnya akumulasi biomassa ini mendukung pemanfaatan $T$. diversifolia sebagai pupuk hijau dengan didukung kandungan hara $\mathrm{N}, \mathrm{P}, \mathrm{K}$ yang tinggi.

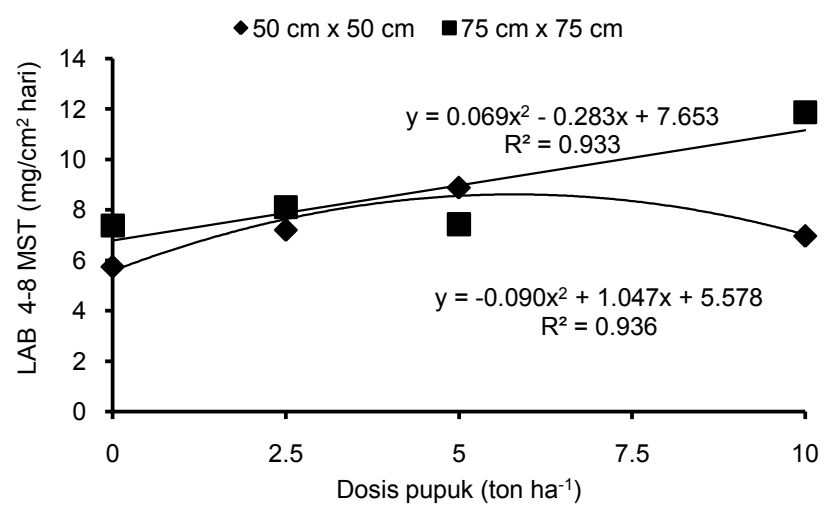

Gambar 3. Interaksi perlakuan dosis pupuk kandang dan jarak tanam pada laju asimilasi bersih (LAB) Tithonia diversifolia 4-8 MST 
Tabel 6. Bobot basah dan bobot kering tajuk serta akar Tithonia diversifolia berdasarkan perlakuan dosis pupuk kandang dan jarak tanam

\begin{tabular}{|c|c|c|c|c|c|c|c|c|}
\hline \multirow[t]{2}{*}{ Peubah } & \multicolumn{4}{|c|}{$\begin{array}{l}\text { Dosis pupuk kandang ayam } \\
\left.\text { (ton } \mathrm{ha}^{-1}\right)\end{array}$} & \multirow[t]{2}{*}{ Rataan } & \multicolumn{2}{|c|}{$\begin{array}{c}\text { Jarak tanam } \\
(\mathrm{cm} \mathrm{x} \mathrm{cm})\end{array}$} & \multirow[t]{2}{*}{ Rataan } \\
\hline & 0 & 2.5 & 5 & 10 & & $50 \times 50$ & $75 \times 75$ & \\
\hline & & & & .... $4 \mathrm{MST}$ & & & & \\
\hline \multicolumn{9}{|l|}{ Bobot basah } \\
\hline Tajuk (g per tanaman) & 193.33 & 189.00 & 182.83 & 168.83 & 183.50 & 198.50 & 168.50 & 183.50 \\
\hline Akar (g per tanaman) & 6.33 & 10.17 & 7.33 & 5.67 & 7.38 & 7.00 & 7.75 & 7.38 \\
\hline Rasio tajuk/akar & 29.41 & 22.77 & 28.99 & 32.86 & 28.51 & 29.97 & 27.04 & 28.51 \\
\hline \multicolumn{9}{|l|}{ Bobot kering } \\
\hline Tajuk (g per tanaman) & 22.71 & 23.56 & 22.87 & 20.64 & 22.45 & 22.51 & 22.38 & 22.45 \\
\hline Akar (g per tanaman) & 1.59 & 2.02 & 1.54 & 1.17 & 1.58 & 1.40 & 1.80 & 1.58 \\
\hline Rasio tajuk/akar & 15.87 & 13.16 & 15.87 & 18.61 & 15.88 & 17.41 & 14.35 & 15.88 \\
\hline \multicolumn{9}{|l|}{ Bobot basah } \\
\hline Tajuk (g per tanaman) & 841.00 & $1,025.00$ & $1,027.20$ & $1,244.20$ & $1,034.35$ & 870.40 & $1,198.3$ & $1,034.35$ \\
\hline Akar (g per tanaman) & 15.87 & 24.50 & 24.00 & 27.17 & 22.89 & 19.93 & 25.83 & 22.89 \\
\hline Rasio tajuk/akar & $66.61 \mathrm{a}$ & $2.87 \mathrm{~b}$ & $44.24 b$ & $45.81 b$ & 49.88 & 50.28 & 49.48 & 49.88 \\
\hline \multicolumn{9}{|l|}{ Bobot kering } \\
\hline Tajuk (g per tanaman) & 151.69 & 196.48 & 193.65 & 233.00 & 193.71 & 162.49 & 224.92 & 193.71 \\
\hline Akar (g per tanaman) & 6.68 & 10.88 & 11.41 & 13.09 & 10.52 & 8.80 & 12.22 & 10.52 \\
\hline Rasio tajuk/akar & 23.72 & 19.23 & 18.65 & 18.41 & 20.00 & 19.85 & 20.15 & 20.00 \\
\hline Laju tumbuh relatif $\left(\mathrm{mg}\right.$ hari $\left.^{-1}\right)$ & 15.29 & 18.53 & 18.72 & $\begin{array}{l}4-8 \mathrm{MS} \\
21.11\end{array}$ & 18.41 & 16.84 & 19.99 & 18.41 \\
\hline
\end{tabular}

Keterangan: Angka yang diikuti oleh huruf yang sama pada baris yang sama tidak berbeda nyata berdasarkan uji DMRT pada taraf 5\%

\section{KESIMPULAN}

Belum diperoleh dosis pupuk kandang optimum untuk produksi biomassa T. diversifolia. Produksi bobot kering biomassa $T$. diversifolia tertinggi dicapai dengan pemberian pupuk kandang 10 ton ha-1 yaitu $1129.1 \mathrm{~kg} \mathrm{ha}^{-}$ ${ }^{1}$ dengan potensi sumbangan hara setara $123.27 \mathrm{~kg}$ urea, $15.36 \mathrm{~kg}$ SP-36 dan $106.93 \mathrm{~kg} \mathrm{KCl}$. Bobot kering biomassa T. diversifolia terbanyak pada jarak tanam $50 \mathrm{~cm}$ x $50 \mathrm{~cm}$ sebesar $897 \mathrm{~kg} \mathrm{ha}^{-1}$ dengan potensi sumbangan hara setara $98.64 \mathrm{~kg}$ urea, $23.97 \mathrm{~kg}$ SP-36 dan $142.32 \mathrm{~kg} \mathrm{KCl}$. Interaksi terjadi pada LAB tanaman umur 4-8 MST, LAB tertinggi pada perlakuan dosis pupuk 10 ton ha $^{-1}$ dan jarak tanam 75 $\mathrm{cm} \times 75 \mathrm{~cm}$ yaitu $11.87 \mathrm{~g} \mathrm{~cm}^{-2}$ hari $^{-1}$.

\section{DAFTAR PUSTAKA}

Adeniyan, B.O., S.O. Ojeniyi, M.A. Awodun. 2008. Relative effect of weed mulch types on soil properties and yield of yam in Southwest Nigeria. J. Soil Nature 2:01-05.
Akpheokhai, I.L., A.O. Claudius-Cole, B. Fawole. 2012. Evaluation of some plant extracts for the management of Meloidogyne incognita on soybean (Glycine max). World J. Agric. Sci. 8:429-435.

Badi H.N., D. Yazdani, S.M. Ali, F. Nazari. 2004. Effect of spacing and harvesting time on herbage yield and quality/quantity of oil thyme, Thymus vulgaris L. Industrial Crop. Prod. 19:231-236.

Barus, L.E. 2005. Pengaruh pemberian pupuk hijau dan fosfat alam terhadap pertumbuhan dan produksi kedelai (Glycine max (L.) Merr) panen muda dengan sistem pertanian organik. Skripsi. Institut Pertanian Bogor. Bogor.

Chagas-Paula, D.A., R.B. Oliveira, B.A. Rocha, F.B. Da Costa. 2012. Ethnobotany, chemistry, and biological activities of the genus Tithonia (Asteraceae). Chem. Biodivers. 9:210-235. 
Chen, S., X. Zhang, H. Sun, T. Ren, Y. Wang. 2010. Effect of winter wheat row spacing on evapotranspiration, grain yield and water use efficientcy. Agric. Water Manag. 97:1126-1132.

Chukwuka, K.S., S. Ogunyemi, I. Fawole. 2007a. Ecological distribution of Tithonia diversifolia (Hemsl). A. Gray-a new exotic weed in Nigeria. J. Biol. Sci 7:709-719.

Chukwuka, K.S., S. Ogunyemi, J.S.A. Osho, G.I Atiri, J.I. Moughali. 2007b. Eco-physiological responses of Tithonia diversifolia (Hemsl) A. Gray in nursery and field conditions. J. Biol. Sci. 7:771-775.

Crespo, G., T.E. Ruiz, J.Alvarez. 2011. Effect of green manure from Tithonia ( $T$. diversifolia) on the establishment and production of forage of $P$. purpureum cv. Cuba CT-169 and on some soil properties. J. Agric. Sci. 45:79-82.

Essiett, U., N. Uriah. 2013. Comparative phytochemical and physicochemical properties of Aspilia africana and Tithonia diversifolia leaves. Int. J. Modern Biol. Med. 3:113-122.

Essiett, U., E.M Akpan. 2013. Proximate composition and phytochemical constituents of Aspilia africana (Pers) C. D. Adams and Tithonia diversifolia (Hemsl) A. Gray stems (Asteraceae). Bull. Environ. Pharmacol. Life Sci. 2:33-37.

Farahani, H.A., S.A. Valadabadi. 2009. Effects of planting density and pattern on physiological growth indices in maize (Zea mays L.) under nitrogenus fertilizer application. J. Agric. Ext. Rural Dev. 2:40-47.

Fatkur, T. Supriyadi, Haryuni. 2010. Pengaruh jarak tanam dan dosis pupuk kandang ayam terhadap pertumbuhan dan hasil tanaman kentang (Solanum tuberosum L.) varietas Granola. Agrineca 10:121-134.

Hakim, N., Agustian, Y. Mala. 2012. Application of organic fertilizer Tithonia plus to control iron toxicity and reduce commercial fertilizer application on new paddy field. J. Trop Soils 17:135-142.

Hartatik, W. 2007. Tithonia diversifolia sumber pupuk hijau. Warta Penelitian Pengembangan Pertanian 29:3-5.

Hayati, Y. 2013. Pemanfaatan pupuk organik dan pupuk hayati dalam peningkatan produksi buncis mini dan perbaikan kualitas tanah. Thesis. Sekolah Pascasarjana. Institut Pertanian Bogor. Bogor.

Jama, B., C.A. Palm, R.J. Buresh, A. Niang, C. Gachengo. 2000. Tithonia diversifolia as a green manure for soil fertility improvement in Western Kenya: A review. Agroforestry Syst. 49:201-221.
Kurniansyah, D. 2010. Produksi kedelai organik panen kering dari dua varietas kedelai dengan berbagai jenis pupuk organik. Skripsi. Institut Pertanian Bogor. Bogor.

Laude, S., Y. Tambing. 2010. Pertumbuhan dan hasil bawang daun (Allium fistulosum L.) pada berbagai dosis pupuk kandang ayam. J. Agroland 17:144-148.

Leopold, A.C., P.E. Kriedemann. 1975. Plant Growth and Development. Tata Mc Grow Hill Publ. Co. Ltd., New Delhi, India.

Liasu, M.O., A.K.K. Achakzai. 2007. Influence of Tithonia diversifolia leaf mulch and fertilizer application on the growth and yield on potted tomato plants. AmericanEurasian J. Agric. Environ. Sci. 2:335-340.

Mayadewi, N.N.A. 2007. Pengaruh jenis pupuk kandang dan jarak tanam terhadap pertumbuhan gulma dan hasil jagung manis. Agritrop 26:153-159.

Melati, M., W. Andriyani. 2005. Pengaruh pupuk kandang ayam dan pupuk hijau Calopogonium mucunoides terhadap pertumbuhan dan produksi kedelai panen muda yang dibudidayakan secara organik. Bul. Agron. 33:8-15.

Melati, M., A. Asiah, D. Rianawati. 2008. Aplikasi pupuk organik dan residunya untuk produksi kedelai panen muda. Bul. Agron. 36:204-213.

Muhsanati, A. Syarif, S. Rahayu. 2008. Pengaruh beberapa takaran kompos Tithonia terhadap pertumbuhan dan hasil tanaman jagung manis (Zea mays saccharata). Jerami 1:87-91.

Oelbermann M., P.S.J. Mustonen, D.C.L. Kass. 2012. Using Tithonia diversifolia (Hemsl.) Gray in a short fallow system to increasing soil phosphorus availability on a Costarican Andosol. J. Agric. Sci. 4:91-100.

Ojeniyi, S.O., S.A. Odedina, T.M. Agbede. 2012. Soil productivity improving attributes of Mexican sunflower (Tithonia diversifolia) and siam weed (Chromolaena odorata). Emir. J. Food Agric. 24:243-247.

Opala, P.A., C.O. Othieno, J.R. Okalebo, P.O. Kisinyo. 2009. Effects of combining organic materials with inorganic phosphorus source on maize yield and financial benefits in western Kenya. Exp. Agric. 46:23-34.

Oyedokun, A.V., J.C. Anikwe, F.A. Okelana, I.U. Mokwunye, O.M. Azeez. 2011. Pesticidal efficacy of three tropical herbal plants' leaf extracts against Macrotermes bellicosus, an emerging pest of cocoa, Theobroma cacao L. J. Biopest. 4:131-137. 
Repková, J., M. Brestič, K. Olšovská. 2009. Leaf growth under temperature and light control. Plant Soil Environ. 55:551-557.

Partey, S.T. 2011. Effect of pruning frequency and pruning height on the biomass production of Tithonia diversifolia (Hemsl) A. Gray. Agroforest Syst. 83:181-187.

Salisbury, F.B., C. Ross. 1995. Fisiologi Tumbuhan. Diah, R., Lukman, Sumaryo (pent.). Institut Teknologi Bandung. Bandung.
Sistani, K.R., F.J. Sikora, M. Rasnake. 2007. Poultry litter and tillage influence on corn production and soil nutrients in a Kentucky silt loam soil. Soil Till. Res. 98:130-139.

Volkenburgh, E.V. 1999. Leaf expansion - an integrating plant behaviour. Plant Cell Environ. 22:1463-1473. 